\title{
Tres miradas sobre el cine santafesino: pasado, presente y futuro
}

- Cine silente vs. cine mudo. El primitivo cine gauchesco santafesino. Ricardo Guiamet

- Cuando llegan las aguas. Inundados de Santa Fe. Sergio Luis Fuster

- La pantalla dibujada. Animación desde Santa Fe. Leandro Arteaga

Editorial Ciudad Gótica, Rosario, 2012

Carolina Anabel Bravi

Facultad de Arquitectura, Diseño y Urbanismo, UNL

El Programa Espacio Santafesino, Estímulo a la Producción Editorial del Ministerio de Cultura de la Provincia de Santa Fe fue iniciado en 2008 con el objetivo de apoyar la producción de las industrias de base cultural de la provincia a través de convocatorias periódicas que abarcan diversos rubros como el editorial, fonográfico, audiovisual, multisoporte y Web. Los textos que se presentan integran la serie Apuntes Cinéfilos de la colección Estación Cine (Editorial Ciudad Gótica) y forman parte de la propuesta ganadora en la edición 201 de este programa. Las obras de la colección están dirigidas a un público amplio desde el punto de vista de un conocedor del medio y ofrecen reflexiones en torno situaciones localizadas en la región, como en este caso, la conformación del campo de la animación en la ciudades de Rosario y Santa $\mathrm{Fe}$, el nacimiento del cine silente en la provincia y los modos en que diversos filmes han abordado la problemática de las inundaciones.

El primer volumen de la serie es el texto de Ricardo Guiamet, Cine silente vs. cine mudo. El primitivo cine gauchesco santafesino. El autor comienza presentado un recorrido histórico por los comienzos del cine en nuestro país, el nacimiento del género gauchesco, los cambios producidos con la incorporación del sonido, la posterior aparición del «sistema de estrellas», las comedias y el cine testimonial. Luego aborda la caracterización del 
cine gauchesco como un género nacional producto de la unión del circo criollo y, la poesía y narraciones gauchescas como Martin Fierro y Juan Moreira. Seguidamente presenta los filmes santafesinos El último malón y El último centauro, la epopeya del gaucho Juan Moreira como ejemplos de esta corriente y analiza los modos en que cada uno despliega el relato cinematográfico.

En el primer caso el autor destaca su valor testimonial, ya que si bien la trama es una historia ficcionada, sucede en el contexto de un hecho real como el alzamiento de la comunidad mocoví en San Javier en 1904, y en el segundo subraya su clara adscripción al género gauchesco. A continuación propone una reflexión en torno a la relación entre estas obras y los westerns, para lo cual detalla sus similitudes y diferencias. Reconoce que, a pesar de estar localizados en ambientes rurales, de desarrollar escenas de acción y combates, de presentar conflictos entre pocos personajes estereotipados y de resaltar el sentido de justicia, libertad y realización individual; el formato norteamericano da cuenta de la irrupción de un mundo nuevo a partir de la conquista del oeste, en cambio el argentino pone en escena el fin de un mundo colonial que se estaba terminando. Finalmente se describen los inicios del cine silente, sus características técnicas y sus limitaciones, y se agregan comentarios sobre cómo este dispositivo, todavía rudimentario, permitió el nacimiento de las bases del discurso cinematográfico tal como lo conocemos hoy.

Cuando llegan las aguases el título del trabajo de Sergio Fuster en el que se realiza un relevamiento de los principales filmes sobre la problemática de la inundación en Santa Fe, en particular los realizados a partir del trágico hecho de abril de 2003. Para ello se comienza describiendo la situación histórica y geográfica de la ciudad, seguidamente se reconstruye lo sucedido en 2003 con testimonios de vecinos afectados y de profesionales de la salud, para finalmente dar cuenta de los terribles saldos. Desde este marco el autor plantea el objetivo de su trabajo: «determinar nuestro ser santafesino, a partir de imágenes de la cotidianeidad de un rincón de la sociedad, tan fuertemente reales, que después de tantos años pueden seguir siendo utilizados, una y otra vez, para la mostración de la intemperie, del triste desamparo del inundado» (Fuster, 20I2:29). A continuación se analizan filmes como Los inundados (Birri, I96I), Inundaciones (Santa Fe Documenta, 2003), Seguir remando (Langhi, 2009), El trompo (Carreras, del Porto, 2005), Reutemann inundador de Santa Fe (La Conjura TV) y Vanesa (Rabaini, 2008).

Los inundados se presenta, retomando los postulados planteados por Fernando Birri para constitución de la Escuela de Cine de Santa Fe, como un filme comercial que plantea un problema de los secto- 
res más pobres desde una mirada crítica al clientelismo. Seguir remando (documental ganador del Concurso de Proyectos de Producción y Realización Audiovisual 2008 otorgado por el Gobierno de la Provincia de Santa Fe) recorre las vivencias de una mujer y una niña durante las inundaciones de 2003 y 2007 , que el autor del texto compara con las historias y personajes del filme anterior. Por otra parte también se incluyen materiales audiovisuales que no circularon por los canales tradicionales como Inundaciones del colectivo de video Santa Fe Documenta, donde se relatan los momentos de constitución del grupo en plena emergencia y la emotiva respuesta que tuvo el filme por parte de los damnificados; y Reutemann inundador de Santa Fe de La Conjura tv, trabajo que intenta convocar al receptora generar una mirada crítica a partir de numerosos testimonios respecto de las polémicas surgidas a partir de esta catástrofe como la cantidad de muertos o el retraso en la rotura de la avenida Mar Argentino. A continuación se comentan el corto premiado El trompo, que cuenta una historia de ficción filmada desde la mirada de un niño con el trasfondo de la inundación, y Vanesa de Mariana Rabaini, donde la directora va desentrañando junto a la entrevistada un relato trágico de dolor y entereza. Finalmente se incluyen tres apartados, un listado de filmes sobre esta temática, un texto sobre las inundaciones en el cine de catástrofe y la reproducción de una nota periodística publicada 2003 en el periódico Rosario I2 donde se reflexiona sobre los vínculos entre lo sucedido entonces y el filme de Fernando Birri.

\section{Al comenzar La pantalla dibujada,} Leandro Arteaga discute sobre la supuesta jerarquía del cine sobre la animación siendo que ambos comparten el mismo rasgo: la persistencia retiniana, y caracteriza al primero, como una filmación «de la vida misma” y al segundo como una sucesión articulada de fotogramas que crean una ilusión de realidad. Luego de ello traza un recorrido cronológico de la animación en la Argentina destacando los trabajos de Cristiani como iniciador, y de Quinterno y García Ferré como consolidadores del género a partir de sus propios esfuerzos individuales y de metodologías autodidactas.

Seguidamente presenta al personaje principal de la animación en Rosario, Luis Bras, y recorre su obra partiendo de sus comienzos vinculados a la publicidad, su encuentro con el realizador Norman McLaren y el giro hacia la experimentación, y su viaje a Canadá; mostrando como esta conjunción de factores fue gestando en este realizador una nueva comprensión del cine animado que unía preocupaciones generales con otras propias del entorno inmediato. Por otra parte relata las condiciones en las que desempeñó su labor docente, las tareas desarrolladas en su taller (donde se produjeron trabajos que circularon por en- 
cuentros y festivales) y cómo finalmente llegó a recibir cierto "reconocimiento lateral» de parte de la Universidad $\mathrm{Na}$ cional de Rosario.

La segunda parte del libro Arteaga la destina a analizar la continuación de la obra de Bras, tras su fallecimiento en I995, llevada adelante por sus alumnos reflexionando sobre el pasaje generacional entre el maestro y la nueva generación. Para ello va describiendo las actividades y las realizaciones de Pablo Rodríguez Jáuregui, quién para el autor fue el discípulo que asumió el legado, de Esteban Tolj, Diego Rolle y José María Beccaría. Luego de describir los trabajos de estos animadores, presenta los principales factores que recientemente han transformado el campo de la animación: las nuevas tecnologías, la institucionalización de la enseñanza con la Escuela Para Animadores de Rosario, y la difusión del género ya sea a través de la televisión como de encuentros y festivales.

Hay un capítulo destinado a la situación en la ciudad de Santa Fe donde se describe la labor de Claudia Ruiz con los adolescentes y niños en la escuela Mantovani y en el Taller El Pibe, las obras de Juan Carlos Buhajeruk, del Grupo El Triángulo, (Del Porto, Carreras, Arroyo) y del Taller de animación Kinder.
Finalmente se presentan trabajos rosarinos reconocidos a nivel internacional destacando la tarea realizada desde las productoras y poniendo en evidencia, no solo el reconocimiento y el impacto de esta práctica en los medios de comunicación sino también su permanencia y vitalidad.

La contribución de este conjunto de textos al estudio de la cinematografía santafesina es relevante por el escaso desarrollo de investigaciones en torno estos temas. Por otra parte desde el punto de vista histórico es valioso el aporte relacionado con los inicios del cine silente santafesino y con el despliegue de la temática de la inundación. Asimismo, el relato del nacimiento y la evolución de la animación toman hoy una importancia significativa ya que tras la incorporación de medios digitales ésta ha adquirido nuevas características en una tendencia que presumiblemente continúe. Por todo ello, estos textos son una contribución importante para pensar el pasado, el presente y el futuro del cine en la región - ya sea entendido como manifestación estética, como producción cultural o como documento histórico- siendo todos ellos un punto de partida y una referencia válida para los trabajos vinculados a estas problemáticas. 